Savina Mihaylova-Goleminova, $P$ h ${ }^{*}$

Chief Assistant Professor in Financial and Tax Law, Department of Administrative Law Studies,

Faculty of Law, St. Kliment University of Sofia Bulgaria
ОРИГИНАЛНИ НАУЧНИ РАД

doi:10.5937/zrpfni1879115M

UDK: 336.227(4-672EU) $341.217(4-672 E U)$

Рад примљен: 30.09 .2018$.

Рад прихваћен: 02.11.2018.

\title{
ACCESSION NEGOTIATION CHALLENGES FACING CANDIDATE COUNTRIES IN THE FIELD OF TAXATION ${ }^{* *}$
}

\begin{abstract}
The Copenhagen Criteriaset out the essential conditions which candidate countries must satisfy in order to become member states.The present paper aims to study theeffects ofopening of the Taxation Chapter in EU accession negotiations for candidate countries, and to present the Bulgarian experience and achievements in this area. The role of the European Union's Instrument for Pre-Accession Assistance (IPA) will be discussed as a major contribution and support in the accession process.The knowledge and implications outlined in the present paper could help to strengthen the role of academic circles in the accession processes of Western Balkan countries in line with the priorities of the BulgarianPresidency of the Council of the EU.In addition to texts in the field of law, the present study and the analyses carried withinhave made use of information published on the Internet, quoting the exact source. The subjectmatter is complex and multifaceted, and the study makes no claims to being exhaustive.
\end{abstract}

Keywords: EU Tax Law, Taxation Chapter in EU accession negotiations, Bulgarian experience.

\footnotetext{
*s.mihaylova@law.uni-sofia.bg

** This paper was presented at the International Scientific Conference "Law in the context of addressing the Challenges of the Contemporary World", held at the Faculty of Law, University of Niš, on $13^{\text {th }}-14^{\text {th }}$ April 2018.
} 


\section{Challenges of EU accession in the area of Taxation}

The objective of the EC is to establish a common market, the operation of which directly concerns interested parties in the Community ${ }^{1}$.The internal market supposesthe abolition of obstacles to the free movement of goods, persons, services and capital between EU Member States (Article 3-6 TEU). TheEuropean Common Market creates enormous opportunitiesfor companies and individuals but raises alot ofissues related to: the EU legal framework on Taxation; fundamental freedoms and fiscal sovereignty;tax rules of the acquis; direct corporate and individual taxation, including the fight against corporate tax avoidance (the European Union's Anti-Tax Avoidance Directive); thefundamental VAT rules and principles such astaxable persons, taxable transactions, deductions, exemptions, supply rules and the acquisition of goods; the role of the European Court of Justice (ECJ); international taxation challenges, International tax jurisdiction, double taxation treaties, OECD Tax policy; the BEPS project.

Even in the absence of taxation issues, the negotiation process holds numerous challenges and requires the mobilisation of the intellectual and physical potential of all stakeholders, such as representatives of the legislative power, the executive power, the judiciary, academic circles, businesses, etc.

In the first place, the Copenhagen Criteria are generally considered to be the essential conditions which a candidate country must satisfy in order to become a member state. The conditions and timing of acandidate's adoption, implementation and enforcement of all current EU rules (the'acquis') are negotiated and the rules are divided into35 different policy fields (chapters), including Chapter 16 Taxation ${ }^{2}$.A candidate country has to accept the acquis before joining the EU and make EU law part of its national legislation. Adoption and implementation of the acquis are the basis of the accession negotiations. ${ }^{3}$ Member States must take all appropriate measures to ensure fulfilment of the obligations arising from the Treaty or from secondary legislation. They must facilitate the achievement of the Community's tasks and abstain from measures which could jeopardise the objectives of the Treaty: Article $10 \mathrm{TFEU}(\mathrm{ex} 5)^{4}$.The biggest challenge, however, is not only the adoption of acquis but its subsequent proper application following

1 Case 26/62 Van Gend en Loos v Nederlandse Administratie der Belastinge [1963]

2 A bilateral screening meeting for Chapter 16 - Taxation was held in Brussels on 5 and 6 March 2015. The delegation of the government of the Republic of Serbia was headed by Mr. Nenad Mijailović, State Secretary in the Ministry of Finance and Head of Negotiating group 16, and Ms. Tanja Miščević, Head of Negotiating Team with the EU. Retrieved on 11 June 2018 from http://www.eu-pregovori.rs/eng/negotiating-chapters/chapter-16-taxation/.

3 Candidate countries negotiation status: https://ec.europa.eu/neighbourhood-enlargement/ countries/check-current-status_en. Retrieved 11 June 2018

4 Case 272/86 Commission v Greece [1988] 
accession. Several of the issues facing our judicial practice and law enforcement are listed further below.

In the second place, in terms of sources of EU law ${ }^{5}$ in the area of taxation, the main concepts and rules apply. Legal doctrine discriminates between three main groups of acts which comprise the so-called primary law and stand foremost in the hierarchy of EU legislation. These are the treaties creating the Union, the acts which amend those treaties and the treaties of accession of new member states. These are all conventional instruments, constituting classic international treaties.

Among the valid treaties are the Treaty on the Functioning of the European Union (TFEU) and the Treaty on European Union (TEU).The EC Treaty is an integral part of the legal system of the Member States and must be applied by their courts. Treaty provisions are capable of creating direct effects both vertically (between the state and individuals) and horizontally (between individuals). EU law consists of the founding treaties (the TEU and the TFEU) and the legal provisions based on the legislative powers delegated to the European Union by the founding treaties. The portion of EU law provisions that may have an effect on taxes is referred to asEU Tax Law.The Charter of Fundamental Rights of the European Union was adopted after entry into force of the Lisbon Treaty on 1 December 2009, and it was decided that the Union shall accede to the ECHR ${ }^{6}$. Human rights play an enormous role in tax cases. The scope of the Charter ${ }^{7}$, however, is limited to cases in which EU law is at issue according to Article 51.

The fundamental rights and the general principles of EU law are protected by the ECJ. Taxpayer rights relate to the main principles of EC law: proportionality; legal certainty; legitimate expectations; fair play; due care principle; protection against arbitrary laws/regulations; equal treatment; no discrimination; right to privacy; right to be taxed fairly; right to be trusted; right to move on right to equal treatment. At present, the issue of taxpayer's rights must be interpreted in light of the new trends, related to Transparency and Data Protection ${ }^{8}$.

5 About EU Law see: Weatherill, S. (2016) Cases and Materials on EU Law. Twelfth Edition. Oxford University Press, Weatherill, S. (2016) Law and Values in the European Union. Oxford University Press

6 With regards to ECJ case-law on human rights as a source of law, see Кръстева, 3. (2015) Разследването на престъпления съгласно ЕСПЧ. Sofia, Sibi, 15-20.

7 Sее Александрова, И., Златарева, М, Панова, Ангелов, Н. (2015) Съдебна защита на основните права в България. Том 1 и 2, НИП; Семов, А. (2018) Права на гражданите на EC. УИ „Св. Климент Охридски”; Христев, Х. (2018) Вътрешен пазар и основни свободи на движение в правото на Европейския съюз. Sofia, Ciela

8 Toptchiyska, D. (2017) The Rule of Law and EU Data Protection Legislation. ORBIT Journal. 1, 1 (Aug. 2017). Retrieved on 13.08.2018 from https://doi.org/https://doi.org/10.29297/ 
The general principles of EU legislation not laid down in the Treaties should also be regarded as primary law. The Treaties expressly recognise the principle of protection of human rights (Article 6 TEU), the principle of non-discrimination (Article $18 \mathrm{TEU}$ ), the principles of subsidiarity (Article 5, para. 3 TEU) and proportionality (Article 5, para. 4 TEU), etc. Others, such as the principle of protection of legitimate expectations and the principle of legal certainty are inferred from the ECJ case-law. Regardless of whether laid down in the Treaties or inferred from legal practice, the general principles of EU law constitute primary sources which should not be contradicted by those standing lower in the hierarchy of sources, otherwise the latter may be repealed by the ECJ pursuant to Article 263 TFEU.

EC measures must not infringe the legitimate expectations of those concerned in the absence of overriding public interest(Legitimate expectations ${ }^{9}$ ).Measures should not exceed what is appropriate and necessary to achieve the objectives in question (Proportionality) ${ }^{10}$.Persons in similar situations should be treated alike unless differential treatment is objectively justified(Equality) ${ }^{11}$. According to the principle of proportionality, thecontent and form of Union action should not exceed what is necessary to achieve the objectives of the Treaties (Article 5 TEU $)^{12}$. Administrative action must comply with the purpose of the law and must not deprive citizens of more than is necessary to achieve this purpose. It is unlawful to apply the law 'stringently' if this will bring about results that were not originally sought by the law. The principle of proportionality fulfils two main functions: it is used as a ground for review of Community measures and as a ground for review of national measures adopting and applying the measures of Community law.

When assessing compliance with the principle of proportionality, the following questions must be considered: whether the action taken is suitable to attain the purpose,and whether the measures of the action are necessary with view of the restrictions and disadvantages that must be sustained with view of attaining the purpose. The EC must act within the limits of the powers conferred on it by

orbit.v1i1.16.

9 Case 120/86 Mulder v Minister van Landbouw en Visserig [1988]

10 Case 181/84 R. v Intervention Board for Agricultural Produce, Ex p. Man(Sugar) [1986]

11 Case 20/71 Sabbatini v EP [1972]

12 In this respect, see:Case C-553/16 ECJ Judgement of the Court of 25July 2018TTL EOOD $v$ Direktor na Direktsia 'Obzhalvane i danachno-osiguritelna praktika' - Sofia. Request for a preliminary ruling under Article 267TFEU from the Varhoven administrativen sad (Bulgarian Supreme Administrative Court, Bulgaria). Retrieved on 13.08.2018 from http://curia.europa. eu/juris/document/document.jsf?text=\&docid=204390\&pageIndex=0\&doclang $=E N \& \bmod$ e $=$ lst $\&$ dir $=\&$ occ $=$ first $\&$ part $=1 \&$ cid $=890164$ 
the Treaty. In areas outside the EC's exclusive competence, the EC must act in accordance with the principle of subsidiarity only if the proposed action cannot be sufficiently achieved by the Member States ${ }^{13}$.

What is the scope of legal instruments in the area of taxation? There is NO exclusive competence (Article 3 TFEU) in the area of Taxation and NO shared competence, excluding indirect taxation (Article 4 TFEU) ${ }^{14}$. Article 6 TFEU (exclusively enumerated actions)applies in the context of taxation.

In general, Member States have broad sovereignty in the area of direct taxation. The acquis on taxation covers extensively the area of indirect taxation: valueadded tax (VAT) $)^{15}$ and excise duties. The European Commission has launched plans for the biggest reform of EU VAT rules in a quarter of a century ${ }^{16}$. In 2016, the Commission presented measures to modernise VAT in the EUto make it simpler, more fraud-proof and business-friendly ${ }^{17}$.Currently, the EU does not use direct taxes for its own recourse collecting purposes.

The provisions of TEU and TFEU in the field of taxation are as follows: Article 4 TEU on Union loyalty (sincere cooperation); Article 18 TFEU prohibiting discrimination based on nationality; Article 21 TFEU on the right of EU citizens to freely move and reside in the European Union; Article 45 TFEU on the free movement of workers; Article 49 TFEU on the right of establishment; Article 56 TFEU on the freedom to provide services; Article 63 TFEU on the free movement of capital and payments; Article 107 TFEU prohibiting state aid; and Article 115TFEUon the authorization to issue directives(the only express measure available for the positive harmonization of direct taxes).

13 Case C-84/94 UKv Council (The Working Time Directive) [1996]

14 Under Art. 4(2)(a) TFEU, the Union and the Member States share competence in the area of internal market.

15 For further information on the VAT system, see: Terra, B., Kajus, J. (2018) Guide to the European VAT Directives 2018. IBFD; EU VAT Compass 2018/2019. (2018) IBFD; de la Feria, R. (2009) The EU VAT System and the Internal Market. IBFD; Lamensch, M. (2015) European Value Added Tax in the Digital Era. A Critical Analysis and Proposals for Reform. IBFD; de la Feria, R. (2013) VAT Exemptions: Consequences and Design Alternatives, The Hague, Kluwer Law International;

16 For more information, see: http://europa.eu/rapid/press-release_IP-17-3443_en.htm. Accessed on 11 June 2018

17 For more information on the Action plan, seet: http://europa.eu/rapid/press-release_IP16-1022_en.htm. Accessed 11 June 2018 
Information related to secondary legislation in the area of Direct Taxation ${ }^{18}$ and Indirect Taxation ${ }^{19}$ can be found on the website of the European Commission.

Existing directives predominantly regulate the area of VAT and excise duties. These apply to each Member State to which they are addressed, but leave to the national authorities the choice of form and methods ${ }^{20}$. An important element is the Sixth VAT Directive (adopted on 17 May 1977), now replaced by Council Directive2006/112/EC of 28November 2006 on the common system of value added tax (VAT Directive).

Article 114TFEU (dealing with internal market measures) and Article 352 TFEU allow the use of regulations.

Regulation is the main legal instrument in the field of customs law ${ }^{21}$. Regulation (EU) No952/2013 of the European Parliament and the Council laying down the Union Customs Code entered into force on 30 October 2013, but its substantive provisions apply in their entirety as of 1 May 2016, once the UCC Delegated and Implementing Acts were adopted: Regulation (EEC) 1658/87 on the customs tariff, regularly amended, and Regulation (EC) 1186/2009 setting up a Community system of reliefs from customs duty (codified version), replacing Regulation (EEC)No918/83 from 1 January 2010.

In the third place, member states face a further challenge: the fight against irregularities and fraud related to public funds from the EU budget, both in terms of revenue and expenditure. VAT is part of the own resources of the Budget of EU (Article 311 TFEU and Council Decision of 26 May 2014 on the system of own resources of the European Union):a uniform rate of $0.3 \%$ is levied on the harmonized VAT base of each member state; the taxable VAT base is capped at $50 \%$ of gross national income (GNI) for each country for the period 2014-202022.

In the context of the EU budget ${ }^{23}$, Article 325 TFEU applies. What exactly is an 'irregularity' according to valid European law? The main regulation providing

18 See: https://eur-lex.europa.eu/summary/chapter/taxation/2101.html?root=2101. Accessed on 11.6. 2018. https://ec.europa.eu/taxation_customs/sites/taxation/files/ taxation_trends_report_2018.pdf. Accessed on 11.6.2018.

19 See: https://eur-lex.europa.eu/summary/chapter/taxation/2102.html?root=2102. Accessed on 11.6. 2018

20 See Case C-131/88 Commission v. Germany and Case C-49/00 Commission v. Italy

21 For further information on valid legislation, see: https://eur-lex.europa.eu/summary/ chapter/customs.html?root_default=SUM_1_CODED=12. Accessed on 11 June 2018

22 Regarding EU Public Finance, see: http://ec.europa.eu/budget/news/article_ en.cfm?id=201501061636. Accessed on 11 June 2018

23 Regulation (EU, Euratom) No 966/2012 of the European Parliament and of the Council of 25 October 2012 on the financial rules applicable to the general budget of the Union and 
legal definition of the term is Council Regulation (EC, Euratom) No 2988/95 of 18 December 1995 on the protection of the European Communities financial interests (in Article 1, para 2).The Convention on the protection of the European Communities' financial interests ${ }^{24}$ also applies.EU countries must introduce effective, proportionate and dissuasive criminal penalties ${ }^{25}$ to deal with fraud affecting the EU's financial interests. The Convention differentiates between fraud in regard to expenditure and revenue. Examples of fraud in respect of revenue include any intentional act or omission such as: the use or presentation of false, incorrect or incomplete statements or documents, which has as its effect the illegal reduction of EU budget resources; non-disclosure of information in violation of a specific obligation with the same effect; or the misapplication of a legally obtained benefit (for example, the misuse of legally obtained tax payments) with the same effect. Fraud is a type of irregularity.

The main factor differentiating an 'irregularity' from 'fraud'26 is the element of deliberate intent: irregularity is a situation in which implementation rules (national law or EU law) are infringed; fraud is a situation in which implementation rules (national law or EU law) are intentionally infringed, with the infringement having a particular purpose - the obtaining of undue advantage.

According to Regulation No.2988/95,Article 4, para, 1 provides: 'As a general rule, any irregularity shall involve withdrawal of the wrongly obtained advantage'; Article 3, para1 provides: 'The limitation period for proceedings shall be four years as from the time when the irregularity referred to in Article 1 (1) was committed. However, the sectoral rules may make provision for a shorter period which may not be less than three years.'; Article 3, para 4 provides: "Member States shall retain the possibility of applying a period which is longer than that provided for in paragraphs 1 and 2 respectively.'

Public interest and the desire to protect the EU budget have prompted the establishment of the European Public Prosecutor's Office (EPPO). On 8 June 2017, twenty EU Member Statesreached a political agreement on the establishment of

repealing Council Regulation (EC, Euratom) No 1605/2002 (OJ L 298, 26.10.2012, p. 1)

24 OJ C 316, 27.11.1995, pp. 48-57

25 See: the Bulgarian Criminal Code, Section IV "Crimes Against the Monetary and Credit System", Art. 255, 255a and Art. 258

26 See: National Strategy for the Prevention and Fight against Irregularities and Fraud affecting the Financial Interests of the European Union for the 2014-2020 period, adopted by means of Protocol No 53 of the session of the Council of Ministers held on 17.12.2014, as well as the Strategy for Combating Fraud affecting the Financial Interests of the European Community, adopted by the Council of Ministers by means of Protocol No 41, item 7/13.10.2005, updated in February 2009 
a new EPPO ${ }^{27}$ under enhanced cooperation. Council Regulation (EU) 2017/1939 establishing the EPPO under enhanced cooperation was adopted by the JHA Council of 12 October 2017 and entered into force on 20 November 2017. On 14 May 2018, the Netherlands notified its intention to participate in the EPPO's enhanced cooperation. Following a build-up phase of three years, the EPPO is envisaged to take up its functions by the end of 2020. The EPPO will be an independent and decentralised prosecution office of the European Union, with the competence to investigate, prosecute and bring to judgment crimes against the EU budget, such as fraud, corruption or serious cross-border VAT fraud. Currently, only national authorities can investigate and prosecute fraud against the EU budget, but their powers stop at national borders. The existing EU-bodies such as Eurojust, Europol and the EU's anti-fraud office (OLAF) lack the necessary powers to carry out criminal investigations and prosecutions.

In the fourth place, with regards to direct taxation, the current challenge at global, European and national level is the prevention of tax fraud, circumvention of tax laws and the restriction of practices associated with 'aggressive tax planning', requiring designated measures to reduce loss to national budgets through improvement of tax legislation and information exchange between the tax administrations of Member States. Member States must comply with the principles of the Code of Conduct for Business Taxation ${ }^{28}$, aimed at the elimination of harmful tax practices (Tsenova, 2017).Administrative co-operation and mutual assistance ${ }^{29}$ between Member States is aimed at ensuring smooth functioning of the internal market as concerns taxation and provide tools to prevent intra-Community tax evasion and tax avoidance. Since its adoption, the original Directive 2011/16/EU has been amended five times, with the aim of strengthening the administrative cooperation among Member States ${ }^{30}$. Member States are required to transpose the amendments of the Council Directive 2011/16/EU of 15 February 2011on administrative cooperation in the field of taxation and repealing Directive 77/799/EEC into national law, and to sign the multilateral Arbitration Convention. Bulgaria is a party to the EU Arbitration Convention (90/436/EEC) on the elimination of double taxation in connection

27 On these issues, see: Тонева, Г. (2017) Европейската прокуратура и българското наказателно и наказателнопроцесуално право. Sofia, Ciela; Legal Barometer: http://www. cli-bg.org/Legal\%20Barometer_broi_15.pdf. Retrieved on 11 June 2018

28 For more information, see: https://ec.europa.eu/taxation_customs/business/companytax/harmful-tax-competition_en, Accessed 11 June 2018

29 See: https://ec.europa.eu/taxation_customs/business/tax-cooperation-control/ administrative-cooperation/enhanced-administrative-cooperation-field-direct-taxation_en. Accessed on 11 June 2018

30 See: https://eur-lex.europa.eu/legal-content/EN/TXT/HTML/?uri=CELEX:02011L001620180101\&from=EN. Accessed on 11 June 2018 
with the adjustment of profits of associated enterprises, which provides that where the commercial or financial relations between two associated enterprises differ from those which would apply between independent enterprises, the profits of those enterprises should each be adjusted as appropriate to reflect the arm's length position. The Convention provides for disputes with fiscal authorities to be referred to an advisory commission, subject to waiver of rights of appeal under domestic law provisions. The Arbitration Convention was first applicable with respect to the 15 original Member States. With respect to the 10 new EU Member States that acceded to the European Union on 1 May 2004, a new Accession Convention was signed on 8 December 2004 (EU Official Journal, C 160, 30 June 2005). The Convention entered into force on 1 July 2008 in relation to Bulgaria and Romania and on 1 January 2015 in relation to Croatia.

Several different initiatives have been developed and implemented in the course of the last few years which modify the elements and principles of familiar taxation systems, prompted by business globalisation, the common European market and trends in the business environment, caused by digitalisation. The first of these is the G20/OECD's Base Erosion and Profit Shifting (BEPS) Project ${ }^{31}$. This project provides for measures at global and European level. The BEPS project is the second major post-financial crisis effort at global cooperation relating to taxation. The first project, which was primarily inter-governmental, involved transparency ${ }^{32}$. The G20 and OECD recently initiated work on tax policy to achieve strong sustainable growth, which may become the next tax cooperation project. The BEPS Project will also give rise to significant reform in the field of treaties for the avoidance of double taxation (Penov, 1999). Implementation of the BEPS project will be reflected on a global scale as it will cover more than 1,100 tax treaties.

Another such initiative is the global automatic information exchange system, created mainly for the needs of the USA Foreign Account Tax Compliance Act (FATCA), and the Multilateral Convention on Mutual Administrative Assistance in Tax Matters, joined by Bulgaria. The Convention includes the Common Reporting Standard (CRS) of the Organisation for Economic Cooperation and Development (OECD).

In order to respond to the abovementioned challenges and to share knowledge, the Bulgarian branch of the International Fiscal Association and the Faculty of Law at Sofia University organized an international tax conference on the topics of BEPS and Enforcement of EU Tax Law in Member States and Legal Remedies

31 See: http://www.oecd.org/tax/beps/

32 See the OECD Report. Retrieved on 13.08.2018 from http://www.oecd.org/tax/ transparency/global-forum-annual-report-2017.pdf 
in EU Tax Law which was held on $18^{\text {th }}$ and $19^{\text {th }}$ May 2017 at Sofia University, Sofia, Bulgaria. ${ }^{33}$ Representatives of different stakeholders attended, exchanged valuable opinions and shared important information.

With view of the above, it is no coincidence that the hottest topic among stakeholders is currently the issue of Tax Transparency. It raises a lot of questions, having in mind the different requirements at global, European and national level ${ }^{34}$.

The table below illustrates the measures undertaken at theECJ level and the EU level, and how these measures have been transposed into the national legislation.

Table 1. Measures taken at the ECJ and the EU level, and their trasposition into the national legislation

\begin{tabular}{|c|c|c|}
\hline OECD & EU & $\begin{array}{c}\text { Transposition in national } \\
\text { legislation }\end{array}$ \\
\hline $\begin{array}{c}\text { Convention on Mutual } \\
\text { Administrative Assistance } \\
\text { in Tax Matters }\end{array}$ & $\begin{array}{c}\text { DAC } 1 \\
\text { Council Directive } \\
\text { 2011/16/EU of } \\
\text { 15 February } 2011 \\
\text { on administrative } \\
\text { cooperation in the field } \\
\text { of taxation and repealing } \\
\text { Directive } 77 / 799 / \mathrm{EEC}\end{array}$ & $\begin{array}{l}\text { Article } 143 \text { TSSPC (regarding the } \\
\text { Convention) } \\
\text { Article } 143 a-\text { Article } 143 r \text { TSSPC }\end{array}$ \\
\hline $\begin{array}{c}\text { CRS } \\
\text { Common Reporting } \\
\text { Standard }\end{array}$ & $\begin{array}{c}\text { DAC } 2 \\
\text { Council Directive } \\
\text { 2014/107/EU of } \\
9 \text { December } 2014 \\
\text { amending Directive } \\
\text { 2011/16/EU as regards } \\
\text { mandatory automatic } \\
\text { exchange of information } \\
\text { in the field of taxation }\end{array}$ & Article $142 a-$ Article $142 z$ TSSPC \\
\hline
\end{tabular}

33 Presentations and information about different initiatives can be found on: http://www. ifa-conference.com/

34 EATLP Congress materials, 7-9 June 2018 in Zurich, Switzerland. Tax Transparency. Retrieved on 11 June 2018 from http://www.eatlp.org/congresses/this-years-congress/3082018-zuerich. 


\begin{tabular}{|c|c|c|}
\hline $\begin{array}{c}\text { BEPS Action } 5 \text { - } \\
\text { compulsory spontaneous } \\
\text { exchange of relevant } \\
\text { information on taxpayer- } \\
\text { specific rulings }\end{array}$ & $\begin{array}{c}\text { DAC } 3 \\
\text { Council Directive } \\
\text { (EU) 2015/2376 of } \\
\text { 8 December } 2015 \\
\text { amending Directive } \\
\text { 2011/16/EU as regards } \\
\text { mandatory automatic } \\
\text { exchange of information } \\
\text { in the field of taxation }\end{array}$ & Article $143 a-$ Article $143 r$ TSSPC \\
\hline \multirow[t]{2}{*}{$\begin{array}{c}\text { BEPS Action } 13 \text { - } \\
\text { Automatic exchange } \\
\text { of Country-by-Country } \\
\text { reporting }\end{array}$} & $\begin{array}{c}\text { DAC 4 } \\
\text { Council Directive (EU) } \\
\text { 2016/881 of } 25 \text { May } \\
\text { 2016 amending Directive } \\
\text { 2011/16/EU as regards } \\
\text { mandatory automatic } \\
\text { exchange of information } \\
\text { in the field of taxation }\end{array}$ & Article $143 \mathrm{t}$ - Article $143 z$ TSSPC \\
\hline & $\begin{array}{c}\text { DAC 5 } \\
\text { Council Directive } \\
\text { (EU) 2016/2258 of } \\
6 \text { December } 2016 \\
\text { amending Directive } \\
\text { 2011/16/EU as regards } \\
\text { access to anti-money- } \\
\text { laundering information } \\
\text { by tax authorities }\end{array}$ & Article 12 TSSPC \\
\hline $\begin{array}{c}\text { BEPS Action 12 - } \\
\text { Mandatory disclosure } \\
\text { rules for aggressive tax } \\
\text { planning schemes } \\
\\
\text { Model Mandatory } \\
\text { Disclosure Rules for CRS } \\
\text { Avoidance Arrangements } \\
\text { and Opaque Offshore } \\
\text { Structures }\end{array}$ & $\begin{array}{c}\text { DAC 6 } \\
\text { Council Directive } \\
\text { (EU) 2018/822 of } 25 \\
\text { May 2018 amending } \\
\text { Directive 2011/16/EU } \\
\text { as regards mandatory } \\
\text { automatic exchange of } \\
\text { information in the field } \\
\text { of taxation in relation to } \\
\text { reportable cross-border } \\
\text { arrangements }\end{array}$ & To be transposed \\
\hline
\end{tabular}




\begin{tabular}{|c|c|c|}
\hline $\begin{array}{c}\text { BEPS Action } 14 \text { - Making } \\
\text { dispute resolution } \\
\text { mechanisms more } \\
\text { effective } \\
\text { BEPS Action } 15 \text { - } \\
\text { Multilateral Instrument } \\
\text { - Improving Dispute } \\
\text { Resolution and } \\
\text { Arbitration }\end{array}$ & \begin{tabular}{|} 
Dispute resolution \\
Council Directive (EU) \\
$2017 / 1852$ of 10 October \\
2017 on tax dispute \\
resolution mechanisms in \\
the European Union
\end{tabular} & To be transposed \\
\hline \begin{tabular}{|} 
BEPS Action 2 - \\
Neutralising the effects \\
of hybrid mismatch \\
arrangements \\
BEPS Action 3 - Designing \\
effective controlled \\
foreign company (CFC) \\
rules \\
BEPS Action 4 - Limiting \\
excessive interest \\
deductions
\end{tabular} & $\begin{array}{c}\text { ATAD } 1 \\
\text { Council Directive (EU) } \\
\text { 2016/1164 of } 12 \text { July } \\
2016 \text { laying down rules } \\
\text { against tax avoidance } \\
\text { practices that directly } \\
\text { affect the functioning of } \\
\text { the internal market }\end{array}$ & To be transposed \\
\hline $\begin{array}{l}\text { BEPS Action } 2 \text { - } \\
\text { Neutralising the effects } \\
\text { of hybrid mismatch } \\
\text { arrangements }\end{array}$ & \begin{tabular}{|c} 
ATAD 2 \\
Council Directive (EU) \\
2017/952 of 29 May 2017 \\
amending Directive (EU) \\
2016/1164 as regards \\
hybrid mismatches with \\
third countries
\end{tabular} & To be transposed \\
\hline
\end{tabular}

In the fifth place, as mentioned above, a huge challenge is how EU law will be applied by the separate member states, given the direct effect of EU Law and Rights and remedies. The discussion thus far has focused on the extent to which EU Law creates rights that are enforceable by individuals in their own national courts. Rights demand remedies. This issue raises the question of state liability in the case of infringements of EU law in the area of taxation and the procedural manner of imposing such liability. 
As mentioned, the main principles of EU law are the direct effect and the supremacy $^{35}$ of EU Acquis. A general principle is that Member States are liable for the infringement of European Union law ${ }^{36}$. The ruling of the ECJ in the Francovich ${ }^{37}$ case established a remedy for damages in cases of breach of EU law.This was conceived as an EU remedy in its own right, and not simply as an option which a particular Member State might or might not choose to embrace ${ }^{38}$.

The ruling on theFrancovich case left open numerous issues concerning the nature of the damages remedy. Many of these were clarified in Brasserie du Pecheur and Factortame ${ }^{39}$. The principle of state liability in damages was held to be general in nature and to exist irrespectively of whether the EU norm which had been broken was directly effective or not. Liability could be imposed irrespective of which organ of the state was responsible for the breach: the legislature, the executive or the judiciary. The ECJ set out the criteria to determine when the state could incur liability. Thus, the ECJ ruled: Where a Member State acted in an area in which it had some measure of discretion, comparable to that of the EU institutions when implementing Union policies, the conditions for liability in damages must be same as those applying to the EU itself. The right to damages was dependent upon three conditions: the rule of law infringed must have been sufficiently serious; and there must have been a direct causal link between the breach of the obligation imposed on the state and the damage which was sustained by the injured parties ${ }^{40}$.

Bulgaria has accumulated experience and practice in the field of state liability in cases of infringement of EU law. In Bulgaria, the procedural rules of action with the closest effect are those set out in the State Liability for Damages Act (SLDA). With view of the contradictory practice in terms of applicable proce-

35 This principle was enunciated in case 6/64 Costa v Enel [1964] It held: "By creating a Community of unlimited duration, having....powers stemming from a limitation of sovereignty, or a transfer of powers from the States to the Community, the Member States have limited their sovereign rights, albeit within limited fields, and thus have created a body of law which binds both their nationals and themselves".

36 See also: Костов. С. (2018) Извъндоговорната отговорност на ЕС и на държавите членки. Sofia, Sibi; Корнезов, Ал. (2012) Отговорността на държавата за нарушаване на правото на Европейския съюз. Sofia, Ciela

37 C-6\&9/90 Francovich v Italian Republic, Bonifaci v Italian Republic [1991] Ross, M. (1993) Beyond Francovich M.L.R.; Craig. P. (1993) Francovich, Remedies and the Scope of Damages Liability, L.Q.R

38 See: Craig, P. (2016) Administrative Law. Sweet\&Maxwell., p.293

39 Case C-46/93 Brasserie du Pecheur SA v Germany, and Joined Cases C-46/93 and C-48/93

R. $v$ Secretary of State for Transport Ex parte Factortame Ltd (No.3) [1996]

40 See Craig, P. (2016) Administrative Law. Sweet\&Maxwell, p.294 
dures and courts competent to review claims for damages caused by the state due to infringement of EU law, an Interpretative case No. 2/2015 of the General Meeting of Judges from the Civil and Commercial Divisions and the General Meeting of Judges from $1^{\text {st }}$ and $2^{\text {nd }}$ Division of the Supreme Administrative Court was initiated upon request of the Chairman of the Supreme Bar Council for the adoption of a joint interpretative decision on the following issues: 1) Which is the competent court to review claims based on Article 4, §3 TEU, which seek to enforce state liability for infringement of EU law? 2) Which is the applicable procedural rule of action for review of claims based on Article 4, §3 TEU? The proceedings under the above interpretative case were stayed by means of Decision dated 09.03.2017 until delivery of the decision of the ECJ under items 1 and 2 of case C-571/2016. The case before theECJ was initiated on the basis of a request for a preliminary ruling by Varna Administrative Court under administrative case No.560/2016. The request raises 8 questions, the first two of which relate to the handling of claims under Article 4, §3 TEU. As of present, the issue regarding the court competent to review claims under Article 4, §3 TEU and the procedure for hearing claims has not been resolved conclusively in practice and the decision under the initiated interpretative case, suspended at a later stage, is still pending.

In the sixth place, it is highly recommended that the experience of those states which acceded to the EU prior to 2004 and 2007 be used in the course of the negotiation period, including experience in the field of taxation, with view of their similar past and culture. Both positive and negative lessons must be taken into account. Work on projects financed through EU funds bring about a shift in thinking and discipline of behaviour, given the strict rules governing the preparation and implementation of such projects, while the exchange of experience and the transfer of knowledge, good practices and expert skills from other member states will serve as guarantee for quality. It is precisely through the financial instruments of cohesion policy ${ }^{41}$ that economic, social and territorial cohesion takes place in the context of the main EU values, as laid out in Article 2 of the Treaty on European Union (TEU), as well asin the Preambles to the Treaty and to the Charter of Fundamental Rights of the EU.

In the seventh place, a huge challenge, not only for Candidate Countries, but also for Member States is compliance with the principle of the Rule of $\mathrm{Law}^{42}$,not only in the field of taxation. The Rule of Law is the backbone of any modern

41 On the topic of the EU Cohesion Policy, see: Goleminova, S. (2017) Financial legal relations within the system of public funds from the European Structural and Investment Funds, Sofia, Ciela Publishing

42 See: Belov, M. (2018) Rule of Law at the Beginning of the Twenty-first Century, Eleven International Publishings, Hague 
constitutional democracy. It is one of the founding principles stemming from the common constitutional traditions of all the Member States of the EU and, as such, one of the main values upon which the Union is based.

It is no accident that the European Commission came up with the idea of tying the transfer of all funds (not only those under the cohesion policy) to the rule of law in its draft proposals for the next EU budget - the Multi-Annual Financial Framework, published on 2 May $2018^{43}$. The mechanism includes the requirement for an independent and effective justice system that would guarantee an effective fight against corruption and abuse while using EU funds, and an effective audit system. Compliance with the rule of law could be applied to all EU policies, but all financial conditionalities would have to be precise and propositional.

Last, but not least, the processes at global, European, regional and national level (not only in the field of taxation), brought about by the new economic and social realities, are increasingly dynamic. This is the place to highlight the priorities of the Bulgarian presidency of the Council of the EU in the area of Taxation. These priorities were outlined in a note ${ }^{44}$ to the EU Council's High Level Working Party on Tax Issues. ${ }^{45}$

\section{Taxation in Bulgaria}

The first question to pose in this context is what actually happened with the Bulgarian negotiation process in the area of Taxation? From the distance of time it should be noted that the actual start of Bulgarian negotiations for accession was15 February 2000. Bulgaria's position with regard to Chapter 10 Taxation was presented at an intergovernmental conference on the negotiations held on 30 April 2001, and the Chapter was temporarily closed on 10 June 2002. The National Revenue Agency was established towards the end of 2002.Since 1 January 2007 Bulgaria has been a Member State of the European Union. The conditions and arrangements for admission are set out in the Protocol annexed to the Treaty concerning the accession of the Republic of Bulgaria and Romania to the EU.

'With the Treaty of Accession of the Republic of Bulgaria to the European Union, ratified by an act passed by the National Assembly on 11 May 2005 (State Gazette

43 See: https://ec.europa.eu/commission/sites/beta-political/files/budget-proposalsfinancial-management-rule-law-may2018_en.pdf and http://ec.europa.eu/budget/mff/ index_en.cfm. Accessed on 11 June 2018

44 See: http://data.consilium.europa.eu/doc/document/ST-5668-2018-INIT/en/pdf accessed on 11 June 2018

45 Priorities in the area of Economic and Financial affairs - presentation to the Committee on Economic and Monetary Affairs (ECON) of the European parliament. Retrieved on 11 June 2018 from http://www.minfin.bg/en/comments/10194 
issue 40/12 May 2005, in force as of 1 January 2007), the Republic of Bulgaria acceded to the European Union. According to Article 2 of the Act Concerning the Conditions of Accession of the Republic of Bulgaria and the Adjustments to the Treaties on which the European Union is Founded, applicable pursuant to Article 2 of the Treaty of Accession of the Republic of Bulgaria to the European Union as of the date of accession, the acts adopted by the institutions prior to the accession are binding for Bulgaria and are applied under the conditions laid down in those Treaties and the Act itself. According to Article 19 of the said Act, the acts listed in Annex III thereto must be adapted as specified in that Annex. Item 4 'Taxation' of Annex III to Article 19 of the Act of Accession lists Sixth Council Directive and its various amendments. According to Article 53 of the Act of Accession, Bulgaria must put into effect the measures necessary for it to comply, from the date of accession, with the provisions of directives and decisions within the meaning of Article 249of the EC Treaty unless another time limit is provided for in the Act. These measures must be communicated to the Commission at the latest by the date of accession or, where appropriate, by the time limit provided for in the Act. The Act does not set out a time limit for the transposition of Sixth Council Directive which means that this should be effected at 1 January 2007, given the text of Article 53 of the Act of Accession. ${ }^{.46}$

The TSSC of 29 December 2005 provides general rules on tax liabilities, liable persons, tax controls, refund of overpaid or unduly paid tax amounts, related parties, methods of determining market prices, limitation periods, collection and execution, etc.

The Republic of Bulgaria adopted and to a considerable extent implemented theacquis in the field of taxation, and did not envisage any major problems with the entry into force of the relevant legislation nor its implementation by the date of accession.

There are however some cases where transitional periods or derogations were achieved.

In the second place, what is the current concept of Bulgarian legal doctrine? According to the generally accepted national legal doctrine tax relations (which are a type of financial legal relations) are covered by the first and fourth group of public relations which fall within the scope of regulation of financial law - those that arise from the distribution of national revenue through taxes, the inflow of

46 Interpretative Decision No 3/06.06.2008 under Interpretative Case No 2/2008 of the General Meeting of Judges from $1^{\text {st }}$ and $2^{\text {nd }}$ Division of the Supreme Administrative Court. Retrieved on 11 June 2018 from: http://www.sac.government.bg/TD_VAS.nsf/ d038edcf49190344c2256b7600367606/fd0e2a1652305ecbc2257e500027fd5b?OpenDoc ument 
funds to the budget and control ${ }^{47}$ over this activity. They also relate to the correlation between the national financial system and that of the European Union.

In this respect, the National Legal Framework includes some basic articles of the Constitution of the Republic of Bulgaria (CRB).According to Article 5 (para. 1) of the CRB and Article 15 (para. 1) of the Law on Legislative Acts (LLA), a legislative act must conform to the CRB and to statutory acts of a higher rank. The CRB introduces the principle that taxes should be established by law (Penov, 2013); according to Article 60 (para. 1), 'Citizens shall pay taxes and duties established by law proportionately to their income and property'. Paragraph 2 of the same article introduces the second fundamental principle of tax law: all tax concessions or surtaxes must also be established by law. The purpose of the principle that taxes must be defined by law is to guarantee interference into the private dominion of taxpayers to the extent and in the manner required by public interest. Tax systems not created on the basis of law are anti-constitutional. By means of Decision No. 3/9 February 1996 under constitutional case No 2/1996, the Constitutional Court ruled that the principle that tax liabilities must be established by law extends to all elements determining the amount of the tax: the taxpayer, the tax base, the tax rate, etc. The provisions of Article $60 \mathrm{CRB}$ clarify that the definition of a taxable person cannot be effected in an interpretative manner but solely through express statutory text." ${ }^{48}$

Other CRB provisions regulating taxation are: Article 84 (item 3), according to which the National Assembly is the body which establishes taxes and determines the size of state taxes - an exclusive obligation which it cannot delegate to the executive power; Article 85 (para. 1, item 4), according to which the National Assembly ratifies or denounces by law all international treaties which contain obligations for the treasury; Article 98 (item 12) - the President is the body which may cancel uncollectible debts to the State; Article 141(para.3) - the municipal council is the body which determines the size of local charges by a procedure, established by law.

Laws take the most prominent place among sources of tax law. Statutory rules related to the budget normally come into effect on 1 January of the respective year and their validity is equal to that of the budget act. The provisions of Article 16 (para. 3) of the Public Finance Act apply to tax laws and their amendments: 'No changes in taxes or compulsory insurance contributions, in terms of all

47 According to the Bulgarian National Audit Office Act $\S 1$, p.11 AP: "Financial control" is any form of control related to management of public means and activities, carried out by specialized authorizations and procedures, including budget control, financial inspection control, tax control, customs control, etc.

48 Interpretative Decision No 3/06.06.2008 under Interpretative Case No 2/2008 of the General Meeting of Judges from $1^{\text {st }}$ and $2^{\text {nd }}$ Division of the Supreme Administrative Court. 
their elements, shall be stipulated to enter into force before the date of entry into force of the state budget act and/or the laws regulating the budget of the National Health Insurance Fund and the public social security budget for the relevant year, or before the date of entry into force of the act amending and supplementing them.'

According to Article 14 (para. 1) LLA, the statutory act can be given retroactive effect only in cases of specific exceptions. In Decision No 9/1996 of the Constitutional Court, the Constitutional Judges share the opinion that citizens need to have advance knowledge of their obligations regarding the state. Article 14 LLA lays down the requirements and exceptions for retroactive effect with the provision that sanctions cannot have a retroactive effect unless where the new sanctions imposed are less severe than the previous ones.

To summarize, sources of material tax laws which regulate the different types of taxes are: the Corporate Income Tax Act; the Income Taxes on Natural Persons Act; the Local Taxes and Fees Act; the Value Added Tax Act; the Excises and Tax Warehouses Act; the Insurance Premium Tax Act. The main procedural act is the Tax and Social Security Procedure Code. The statutory rules of other acts which are not part of tax legislation but nevertheless comprise sources in this context are: the Administrative Violations and Sanctions Act, the Interest on Taxes, Fees and Other Similar State Receivables Act; the Customs Act; the State Aid Act; the Currency Act. As noted, the Administrative Procedure Code and the Civil Procedure Code have subsidiary effect. Individual provisions from other acts are also applied in the regulation of tax relations, such as those of the Commercial Act, the Obligations and Contracts Act, the Local Self-Government and Local Administration Act, etc. Many by-laws also serve to regulate tax relations: ministerial decrees adopting rules and ordinances; instruments issued by the minister of finance, etc. The significance of the ordinances adopted by Municipal Councils in determining the amount of local taxes pursuant to the Local Taxes and Fees Act should not be overlooked.

In terms of international bilateral agreements concluded by Bulgaria, another source of tax law are any Treaties for the Avoidance of Double Taxation ${ }^{49}$. These serve as basis for the avoidance of levying direct taxes on the income and property of taxable entities by two or more jurisdictions. Bulgaria has an extensive treaty network ${ }^{50}$. The treaties generally follow the OECD Model Convention even though Bulgaria is not an OECD Member country. However, some of the treaties

49 Art.135-142 TIPC sets out the procedure for application of the treaties for the avoidance of double taxation of the income and property of foreign persons

50 See the complete list of tax treaties signed by Bulgaria at the NRA website: http://www. nap.bg/en/page?id=530. Retrieved 11 June 2018 
contain the definition of a permanent establishment, which follows the UN Model Convention. Treaty provisions prevail over domestic law provided that the treaty is duly ratified, entered into force and officially promulgated inthe State Gazette. According to Article 5 (para. 4) of the Constitution, International treaties which have been ratified in accordance with the constitutional procedure, have been promulgated and have come into force with respect to the Republic of Bulgaria are part of the legislation of the State. They have primacy over any conflicting provisions of the domestic legislation. This rule applies to international conventions as well.

\section{STRUCTURE OF BULGARIAN TAX SYSTEM}

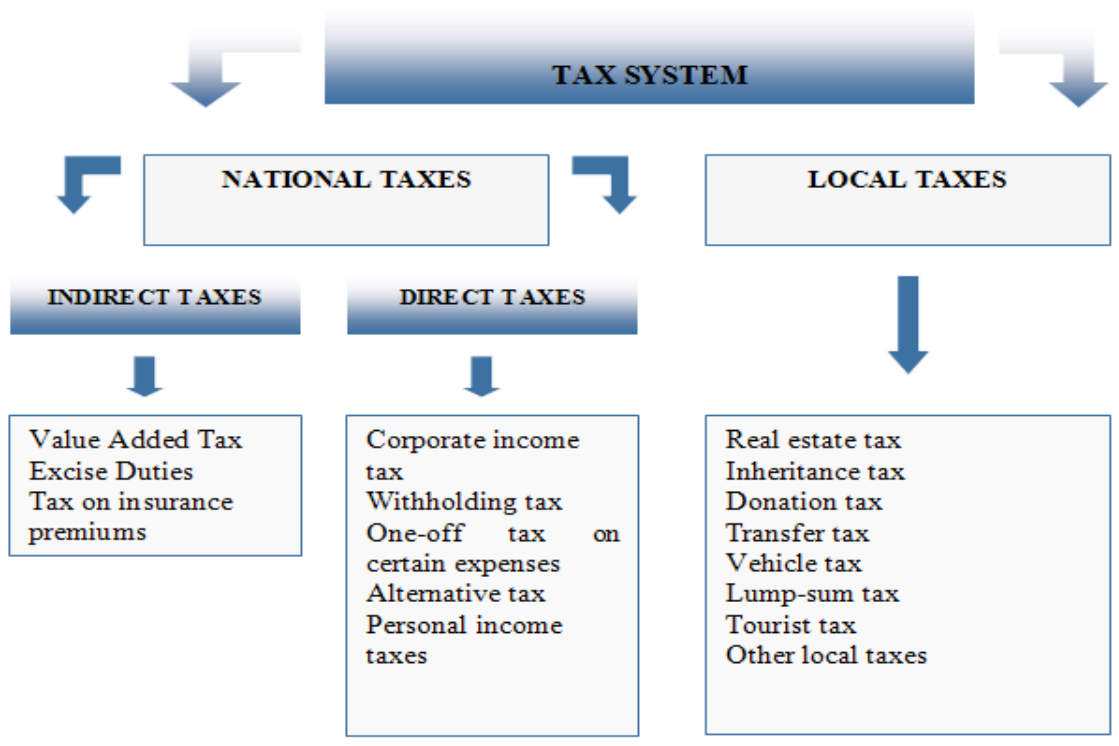

Revenue authorities have certain powers laid down in the Tax and Social Security Procedure Code and substantive tax laws. Their legal capacity is expressed in their competence as a sum of powers assigned to them by law. The powers of a revenue authority and a public enforcement authority are laid down in the National Revenue Agency Act and the Tax and Social Security Procedure Code, with municipal administration officers (Article 4 of the Local Taxes and Fees Act)

51 For more information see:http://www.minfin.bg/bg/770 and http://nap.bg/page?id=428, Accessed on 11 June 2018 
and customs authorities (Article 104 of the Excise Duties and Tax Warehouses Act) also being treated as revenue authorities.

\section{Conclusions}

Bulgaria has accumulated invaluable experience in the application of EU Tax Law in the area of Direct and Indirect Taxation. The resulting best practices can be transferred to all possible areas of cooperation: administrative; academic; judicial; business. In this respect, the European Union's Instrument for Pre-Accession Assistance (IPA)could make a major contribution and provide support in the accession process for: development of administrative capacity of tax authorities; regional partnership and exchange of best practices for the development of legal, institutional and methodological frameworks for the tax system and tax control and prevention of fraud; enhancing the competitiveness of the national economy, strengthening its ability to withstand the competitive pressures of the single market, reducing disparities; compliance with accession requirements not only in the area of taxation. We should not forget that the Western Balkans countries need a clear European perspective and connectivity among them and with other Member States. Academic circles may playa very crucial and strategic role in this process. The Bulgarian Presidency works purposefully for return of the topic of the Western Balkans on the EU agenda, and has taken responsibility and raised these issues for discussion, outlining the measures for their overcoming. The implementation of the Rule of Law in the area of tax law and taxation creates trust among the Member States.

\section{References}

Literature in Bulgarian

Александрова, И., Златарева, М, Панова, Ангелов, Н. (2015) Съдебна защита на основните права в България. Том 1 и 2, НИП;

Костов. С. (2018) Извъндоговорната отговорност на EC и на държавите членки. Sofia, Sibi;

Корнезов, Ал. (2012) Отговорността на държавата за нарушаване на правото на Европейския съюз. Sofia, Ciela

Кръстева, 3. (2015) Разследването на престъпления съгласно ЕСПЧ. Sofia, Sibi, 15-20.

Пенов, С. (2013) Принципът на законоустановеност на данъчните задължения в Република България в практиката на Конституционния съд Сборник: Римско и съвременно публично право, София, Университетско издателство 
Пенов, С. (2003)Прилагане на спогодбите за избягване на двойното данъчно облагане на доходите и имуществата според процедурата в ДПКСп. „Финанси и право“,бр.8/9

Пенов, С. (2002) Проблеми по прилагането на спогодбите за избягване на международното двойното данъчно облагане на доходите и имуществото. Cn. "Право без граници"

Пенов, С. (1999) Избягване на двойното данъчно облагане на доходите и имуществата чрез норми на националното данъчно право.Cn. „Административно правосъдие“, кн.3

Пенов, С. (1999).Правен режим на спогодбите за избягване на международното двойно данъчно облагане.Данъчен наблюдател, кн. 1.

Пенов, С. (1997).Действие на договорите за избягване на международното двойно данъчно облагане.Сn. „Финансово-данъчен контрол“, кн.2

Пенов, С. (1996) Понятие за международно двойно данъчно облагане.Cn. „Финансово-данъчен контрол“,кн.8

Пенов, С. (1996)Регулативно действие на нормите на международните договори за избягване на двойното данъчно облагане на доходите и имуществата.Сn. „Търговско и данъчно право“,кн.4 и кн.5

Пенов, С. (1996) Методи за избягване на международното двойно данъчно облагане.Сn. „Търговско право“, кн.3

Семов, А. (2018) Права на гражданите на ЕС. УИ „Св. Климент Охридски”

Славчева, И., Стефанов, А. (2012) Спогодби за избягване на двойното данъчно облагане, сключени от Р България,Sofia, Ciela

Тонева, Г. (2017) Европейската прокуратура и българското наказателно и наказателнопроцесуално право. Sofia, Ciela;

Христев, Х. (2018) Вътрешен пазар и основни свободи на движение в правото на Европейския съюз.Sofia, Ciela

Ценова, Л. (2017) Данъчно облагане-съвременнитенденции. Авангард прима Literature in English

Belov, M. (2018) Rule of Law at the Beginning of the Twenty-first Century, Eleven International Publishings, Hague

Administrative cooperation in (direct) taxation in the EU. Retrieved on 11 June 2018 from https://ec.europa.eu/taxation_customs/business/tax-cooperationcontrol/administrative-cooperation/enhanced-administrative-cooperationfield-direct-taxation_en 
Bulgarian Criminal Code, Section IV “Crimes Against the Monetary and Credit System" art. 255, 255a and art. 258

Candidate countries negotiation status: https://ec.europa.eu/neighbourhoodenlargement/countries/check-current-status_en. Retrieved 11 June 2018

Case C-46/93 Brasserie du Pecheur SA v Germany and Joined Cases C-46/93 and C-48/93 R. v Secretary of State for Transport Ex parte Factortame Ltd (No.3) [1996]

Case C-131/88 Commission v. Germany and Case C-49/00 Commission v. Italy

Case 6/64 Costa v Enel [1964]

C-6\&9/90 Francovich v Italian Republic, Bonifaci v Italian Republic [1991]; Ross, M. (1993) Beyond Francovich M.L.R.; Craig. P. (1993) Francovich, Remedies and the Scope of Damages Liability, L.Q.R

Case C-553/16 ECJ Judgement of the Court of 25July 2018TTL EOOD v Direktor na Direktsia 'Obzhalvane i danachno-osiguritelna praktika'-Sofia. Retrieved on13.08.2018 from http://curia.europa.eu/juris/document/document.jsf?text $=\&$ docid $=204390 \&$ pageIndex $=0 \&$ doclang $=E N \&$ mode $=$ lst $\&$ dir $=\& o c c=$ first $\&$ pa $\mathrm{rt}=1 \& \mathrm{cid}=890164$

Case 120/86 Mulder v Minister van Landbouw en Visserig [1988]

Case 181/84 R.v Intervention Board for Agricultural Produce, Ex p. Man(Sugar) [1986]

Case 20/71 Sabbatini v EP [1972]

Case C-84/94 UKv Council (The Working Time Directive) [1996]

Case 26/62 Van Gend en Loos v Nederlandse Administratie der Belastinge [1963]

Council Directive 2011/16/EU of 15 February 2011 on administrative cooperation in the field of taxation and repealing Directive 77/799/EEC. Retrieved on 11 June 2018 from: https://eur-lex.europa.eu/legal-content/EN/TXT/ HTML/?uri=CELEX:02011L0016-20180101\&from=EN

Craig, P. (2016) Administrative Law. Sweet\&Maxwell., p.293-294

de la Feria, R. (2009) The EU VAT System and the Internal Market. IBFD

de la Feria, R. (2013) VAT Exemptions: Consequences and Design Alternatives, The Hague, Kluwer Law International;

Direct Taxation. Retrieved on 11 June 2018 from: https://eur-lex.europa.eu/ summary/chapter/taxation/2101.html?root=2101EU VAT System Reform. Retrieved on 11 June 2018 from: http://europa.eu/rapid/press-release_IP-173443_en.htm 
EATLP Congress materials on Tax Transparency (7-9 June 2018), Zurich, Switzerland. Retrieved on 11 June 2018 from http://www.eatlp.org/congresses/ this-years-congress/308-2018-zuerich.

EU Budget for the Future. Retrieved on 13 August 2018 from: http://ec.europa. eu/budget/mff/index_en.cfm

EU Budget Summary. Retrieved on 13 August 2018 from: https://ec.europa.eu/ commission/sites/beta-political/files/budget-proposals-financial-managementrule-law-may2018_en.pdf

EU Public Finance. Visit: http://ec.europa.eu/budget/news/article_ en.cfm?id=201501061636.

Goleminova, S. (2017) Financial legal relations within the system of public funds from the European Structural and Investment Funds, Sofia, Ciela Publishing

Harmful Tax Competition. Code of Conduct. Retrieved on 11 June 2018 from: https://ec.europa.eu/taxation_customs/business/company-tax/harmful-taxcompetition_en, Accessed on 11 June 2018

Indirect taxation. Retrieved on 11 June 2018 from: https://eur-lex.europa.eu/ summary/chapter/taxation/2102.html?root $=2102$

IFA initiatives and Presentations. Retrieved on 13.08.2018 from: http://www. ifa-conference.com/

Interpretative Decision No 3/06.06.2008 under Interpretative Case No 2/2008 of the General Meeting of Judges from $1^{\text {st }}$ and $2^{\text {nd }}$ Division of the Supreme Administrative Court. Retrieved from: http://www.sac.government.bg/TD_VAS. nsf/d038edcf49190344c2256b7600367606/fd0e2a1652305ecbc2257e500027 fd5b?OpenDocument,11 June 2018

Interpretative Decision No 3/06.06.2008 under Interpretative Case No 2/2008 of the General Meeting of Judges from $1^{\text {st }}$ and $2^{\text {nd }}$ Division of the Supreme Administrative Court.

Lamensch, M. (2015) European Value Added Tax in the Digital Era. A Critical Analysis and Proposals for Reform. IBFD

Legal Barometer (2017), issue 15 [Electronic version]. Retrieved 11 June 2018 from: http://www.cli-bg.org/Legal\%20Barometer_broi_15.pdf

List of tax treaties signed by Bulgaria. Retrieved on 11 June 2018 from: http:// www.nap.bg/en/page?id=530

National Strategy for the Prevention and Fight against Irregularities and Fraud affecting the Financial Interests of the European Union for the 2014-2020 period 
OECD BEPS Project. Retrieved on 11 June 2018 from: http://www.oecd.org/ tax/beps/

Priorities in the area of Economic and Financial affairs - presentation to the Committee on Economic and Monetary Affairs (ECON) of the European parliament. Retrieved on 11 June 2018 from http://www.minfin.bg/en/comments/10194

Regulation (EU, Euratom) No 966/2012 of the European Parliament and of the Council of 25 October 2012 (OJ L 298, 26.10.2012, p. 1)

Strategy for Combating Fraud affecting the Financial Interests of the European Community, updated in February 2009

Structure of the Bulgarian Tax System. Retrieved on 11 June 2018 from:http:// www.minfin.bg/bg/770 and http://nap.bg/page?id=428

Taxation Trends in the EU - Report. Retrieved on 11 June 2018 from: https:// ec.europa.eu/taxation_customs/sites/taxation/files/taxation_trends_report_2018.pdf

Tax Policy Roadmap of the Bulgarian Presidency of the Council. Retrieved on 13 August 2018 from: http://data.consilium.europa.eu/doc/document/ST-56682018-INIT/en/pdf

Tax Transparency Report. Retrieved on 13.08.2018 from http://www.oecd.org/ tax/transparency/global-forum-annual-report-2017.pdf

Terra, B., Kajus, J. A (2018) Guide to the European VAT Directives 2018. IBFD; EU VAT Compass 2018/2019. (2018) IBFD

Toptchiyska, D. (2017) The Rule of Law and EU Data Protection Legislation. ORBIT Journal. 1, 1 (Aug. 2017). Retrieved on 13.08.2018 fromhttps://doi.org/https:// doi.org/10.29297/orbit.v1i1.16.

Valid Customs Legislation. Retrieved on 11 June 2018 from: https://eur-lex. europa.eu/summary/ chapter/customs.html?root_default=SUM_1_CODED=12

VAT Action plan. Retrieved on 11 June 2018 from: http://europa.eu/rapid/pressrelease_IP-16-1022_en.htm.

Weatherill, S. (2016) Cases and Materials on EU Law. Twelfth Edition. Oxford University Press

Weatherill, S. (2016) Law and Values in the European Union. Oxford University Press 


\title{
Др Савина Михајлова-Големинова,
} Виши доцент, Одсек за Управно право, Правни факултет, Универзитет св. Климент Охридски у Софији, Република Бугарска

\section{ИЗАЗОВИ ПРЕГОВАРА О ПРИСТУПАЫУ ЗЕМАЉА КАНДИДАТА У ОБЛАСТИ ОПОРЕЗИВАЊА}

\begin{abstract}
Резиме
Копенхагенски критеријуми су основни услов који држава кандидат мора испунити да би постала држава чланица Европке уније. Циљ рада је да размотри последище отварања Поглавља о опорезивању у преговорима о приступању земаља кандидата, и да представи искуство и достигнућа Бугарске у овој области. Биће представљена и важна улога Инструмента предприступне помоћи (ИПА), који представља велики допринос и подршку Европске уније земљама кандидатима у процесу придруживања. Информације и импликације наведене у овом раду могу допринети већем учешћу академских кругова у процесу придруживања земаља западног Балкана, у складу са приоритетима бугарског председавања Саветом Европске уније.
\end{abstract}

Кључне речи: Пореско право Европске уније, Поглавље о опорезивању, преговори о приступању земаља кандидата, Инструмент предприступне помоћи (ИПА) Европској унији, искуство Бугарске. 
